Vol 11, Issue 12, 2018

\title{
THE PHYSIOCHEMICAL AND ANTIBACTERIAL PROPERTIES OF GALACTOMANNAN EDIBLE FILM OF ARENGA PINNATA INCORPORATED WITH ZINGIBER OFFICINALE ESSENTIAL OIL
}

\author{
JULIATI BR TARIGAN*, IRWANA NAINGGOLAN, JAMARAN KABAN \\ Department of Chemistry, University of Sumatera Utara, Medan, Indonesia. Email: juliati@usu.ac.id
}

Received: 22 June 2018, Revised and Accepted: 20 July 2018

\begin{abstract}
Objective: This study aimed to demonstrate the incorporation of Zingiber officinale essential (ZOE) oil onto galactomannan from Arenga pinnata (GAP) matrix and determined the antibacterial activity of the edible films (EF).

Methods: EF was obtained from the incorporation of GAP ( $0.5,0.9$, or $1.3 \mathrm{~g})$ with ZOE ( 0.5 or 1 g) using glycerol ( 0.6 g) and monoglycerol oleic ( 0.2 g) as a plasticizer.

Results: The thickness of the films increased with the increase of GAP and ZOE oil. However, the tensile strength and water permeability decreased in the fourth EF when the ZOE oil was increased. The maximum value of tensile strength and modulus elongation was obtained with the ratio of GAP to ZOE oil at $0.9,0.5,4.502 \mathrm{MPa}$, and $0.0633 \mathrm{MPa}$, respectively. The Fourier transform infrared spectrum showed that the interaction occurred between GAP and ZOE oil. The EFs showed antibacterial activity against Escherichia coli, Staphylococcus aureus, Shigella dysenteriae, Salmonella typhi, Pseudomonas aeruginosa, Candida albicans, and Saccharomyces cerevisiae with the highest activity in the third EF. The total bacteria amount in a colony decreased until the $5^{\text {th }}$ day compared with the control. Furthermore, the third EF could inhibit oxygen migration with a respiratory quotient of 7.71.
\end{abstract}

Conclusions: This study revealed that EFs from GAP and ZOE could be prepared and have antibacterial activity against several pathogenic bacteria.

Keywords: Edible film, Galactomannan, Arenga pinnata, Zingiber officinale, Essential oil, Antibacterial.

(C) 2018 The Authors. Published by Innovare Academic Sciences Pvt Ltd. This is an open access article under the CC BY license (http://creativecommons. org/licenses/by/4. 0/) DOI: http://dx.doi.org/10.22159/ajpcr.2018.v11i12.28061

\section{INTRODUCTION}

Recently, there is increasing interest in the identification of the properties of antibacterial products from natural sources, which are usually used in the preservation of food or health food. The edible film (EF) could give extra protection to food and also has some advantages such as biodegradability and environmental friendliness. The EF can be used to enhance food quality and keep the food fresh in storage. Some compounds, for example, antioxidants, antimicrobials, and flavor can be added to the EF, which can increase its stability, quality, functionality, and safety of the food [1-5]. Based on our research, an EF from galactomannan of Arenga pinnata (GAP) incorporated with the essential oil of Ocimum basilicum has antioxidant and antibacterial properties [6].

Based on our knowledge, only limited research exists about the characterization and application of galactomannan as EF and coating compared with other polysaccharides. However, current research on galactomannan has shown a new perspective about the properties and usage of galactomannan for EF and coating, based on the specific property of galactomannan solution which forms a viscous liquid with water even in low concentrations [7-9].

One of the galactomannan sources is A. pinnata or "kolang-kaling" in Indonesia. Galactomannan contained in A. pinnata is $4.58 \%(\mathrm{w} / \mathrm{w})$ with antioxidant activity $\left(\mathrm{IC}_{50}\right)$ of $20.45 \mathrm{ppm}$ based on the DPPH method [10]. However, utilization of GAP for EF and coating remains limited. Extract of ZOE oil extracts, water extract, and residue extract has been tested for their antioxidant properties using the DPPH method [10]. ZOE extract can be produced using the hydrodistillation method $[11,12]$ and has been identified as having positive antimicrobial activity against bacteria such as B. subtilis, Staphylococcus aureus, and K. pneumonia, and fungi such as Aspergillus niger, Penicillium notatum, Mucor hiemalis, and Fusarium oxysporum [13]. However, to the best of our knowledge, ZOE has never been incorporated into GAP to form an EF. The physicochemical properties of EF from GAP incorporated with ZOE have to be tested before the EF is applied to food.

To address this issue, we studied the physicochemical properties of EF from GAP incorporated with ZOE. The thickness of the films, water permeability, thermal decomposition, tensile strength, surface morphology, and antibacterial activity was also studied against seven bacteria. Antibacterial activity against seven bacteria was conducted using Oreochromis niloticus fish and determined using the standard plate count method.

\section{MATERIALS AND METHODS}

\section{Materials}

The materials used in this study were galactomannan extracted from A. pinnata and Zingiber officinale, which were obtained from a local market in Medan, North Sumatera, Indonesia. Glycerol (99.5\%) was obtained from the oleochemicals industry in Medan, and calcium chloride was obtained from Merck.

\section{Methods}

Preparation of GAP and ZOE

Extraction of GAP in neutral conditions was based on the method of a previous researcher with slight modification [7]. The result of this process has been published [6]. The ZOE used in this study was obtained according to the following method which has been published [13]. The chemical composition of $\mathrm{ZOE}$ also has been published.

\section{Preparation of EF from GAP incorporated with ZOE}

The EF preparation was performed as described in Cerqueira et al. with some changes [7]. The film was prepared using various quantities of galactomannan $(0.5,0.9$, and $1.3 \mathrm{~g})$ and ZOE $(0.5$ and $1.0 \mathrm{~g})$ while the 
amounts of glycerol at $0.6 \mathrm{~g}$ and monoglycerol oleic (MGO) at $0.2 \mathrm{~g}$ were the same for each film. The formulation for each film is described in Table 1. Galactomannan solution was prepared by dissolving galactomannan with water in a $100 \mathrm{~mL}$ volumetric flask at room temperature, followed by the addition of glycerol and MGO. After stirring for $2 \mathrm{~h}$, the appropriate weight of ZOE was added and stirred for $5 \mathrm{~min}$. Then, $75 \mathrm{~mL}$ of solution was poured onto a glass plate $(13 \mathrm{~cm} \times 13 \mathrm{~cm})$ and dried in an oven at $35^{\circ} \mathrm{C}$ for $20 \mathrm{~h}$ and then stored in a desiccator before testing. The physicochemical properties of the EF were determined according to the thickness, water permeability, tensile strength, thermal decomposition, and Fourier transform infrared (FT-IR).

\section{Thickness studies}

The thicknesses of the EF were tested using a micrometer (Tricle brand) by measurement at five different points randomly. The mean of the thickness was used to determine water vapor permeability or water permeability transfer rate.

\section{Water vapor permeability studies}

Water vapor permeability was determined based on the ASTM E9600 (ASTM 2000b) method with slight modification and based on a gravimetric test [7]. Cell permeation was tested using a plastic material with a diameter of $4.4 \mathrm{~cm}$ and height of $3 \mathrm{~cm}$, containing $25 \mathrm{~g}$ of silica gel $(0 \%$ of humidity and $0 \mathrm{~Pa}$ of pressure). Each cell was perforated with a $1.3 \mathrm{~cm}$ diameter hole onto which EF was pasted. Next, the cell was stored in a desiccator containing water distillate to form $100 \%$ humidity and water vapor pressure of $2337 \mathrm{~Pa}$ at $20^{\circ} \mathrm{C}$. Each cell was weighed every $2 \mathrm{~h}$ for $12 \mathrm{~h}$. Then, the slope was measured based on the increase of silica to time with regression. Each experiment was performed in two replicates. The water vapor transmission rate (WVTR) was calculated based on equation below [14].

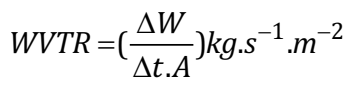

Where, $\mathrm{DW} / \mathrm{Dt}=$ the amount of water absorbed per time

\section{Antimicrobial activity}

The antimicrobial activity test of the EF from GAP incorporated with ZOE was conducted following the method described in previous research [6]. All the films were cut aseptically with a diameter of films were $6 \mathrm{~mm}[6]$.

Table 1: Formulation of EF from GAP incorporated with ZOE

\begin{tabular}{lllll}
\hline EF & \multicolumn{2}{l}{ Formulation } & & \\
\cline { 2 - 5 } & GAP (g) & ZOE (g) & Glycerol (g) & MGO (g) \\
\hline $\mathrm{EF}_{1}$ & 0.5 & 0.5 & 0.6 & 0.2 \\
$\mathrm{EF}_{2}$ & 0.5 & 1.0 & 0.6 & 0.2 \\
$\mathrm{EF}_{3}$ & 0.9 & 0.5 & 0.6 & 0.2 \\
$\mathrm{EF}_{4}$ & 0.9 & 1.0 & 0.6 & 0.2 \\
$\mathrm{EF}_{5}$ & 1.3 & 0.5 & 0.6 & 0.2 \\
$\mathrm{EF}_{6}$ & 1.3 & 1.0 & 0.6 & 0.2 \\
\hline
\end{tabular}

EF: Edible film, GAP: Galactomannan from Arenga pinnata, ZOE: Zingiber officinale essential
Determination of bacteria using standard plate count method

The $O$. niloticus fish bought from the local market was cleaned and cut into small sizes to weigh $1 \mathrm{~g}$ each and wrapped with $\mathrm{EF}_{3}$ and ZOE $(0.5 \%$ in DMSO). The sliced, wrapped fish was stored in plastic containers at $5-10^{\circ} \mathrm{C}$ for 10 days, with an unwrapped fish as a control. The standard plate count method was used to determine the amount of bacteria growth on day $0,1,2,3,5$, and 9 using a colony counter. Each sample was put into a tube and $10 \mathrm{~mL}$ of distillate water was added. Next, the sample was diluted to 10,000 times with distillate water and $10 \mathrm{~mL}$ PCA media was added. $1 \mathrm{~mL}$ of sample was then poured into a tube and vortexed for $1 \mathrm{~min}$, then poured into a Petri dish and homogenized by shaking. The density of the bacterial cell was counted after incubation for $24 \mathrm{~h}$ at $37^{\circ} \mathrm{C}$ using the equation below [15].

$$
\sum \text { Cell }=\sum \text { colony } \times \frac{1}{\text { dillution factor }}
$$

\section{Respiration rate analysis}

The respiration rates of fresh 0 . niloticus fish wrapped and unwrapped were conducted using a respiratory chamber equipped with a rubber stopper. Approximately $200 \mathrm{~g}$ of wrapped and unwrapped fish was placed in the chamber, and the chamber lid was sealed with vacuum grease to avoid in/out $\mathrm{O}_{2}$ and $\mathrm{CO}_{2}$ gases. The chamber was stored at $10^{\circ} \mathrm{C}$. For determination of $\mathrm{O}_{2}$ and $\mathrm{CO}_{2}$ gases concentration, two holes were made using plastic pipe. The concentration of gases was determined using a cosmotector and calculated using the equation below.

$\mathrm{R}_{\mathrm{r}}=\frac{10^{3} \times M_{w} \times \frac{\Delta C}{100} \times\left(V-\frac{W}{\tilde{A}}\right)}{R \times W \times \Delta T \times\left(273+t_{0}\right)}$

Where,

$\mathrm{R}_{\mathrm{r}}=$ Production rate of $\mathrm{CO}_{2}$ or consumption rate of $\mathrm{O}_{2}(\mathrm{ml} / \mathrm{kg}$-jam $)$

$\mathrm{M}_{\mathrm{w}}=$ Molecular weight $\left(\mathrm{CO}_{2}=44\right.$ and $\left.\mathrm{O}_{2}=32\right)$

$\Delta \mathrm{C}=$ Deviation concentration of $\mathrm{O}_{2}$ or $\mathrm{CO}_{2}(\%)$ between two measurements

$\mathrm{V}=$ Container volume (l)

$\mathrm{R}=$ Constanta gas $\left(0.0821 \mathrm{dm}^{3} \cdot \mathrm{atm} / \mathrm{K} / \mathrm{mol}\right)$

$\mathrm{W}=$ Weight of sample $(\mathrm{kg})$

$\sigma=$ density $(\mathrm{kg} / \mathrm{L})$

$\mathrm{t}=$ Storage temperature $\left({ }^{\circ} \mathrm{C}\right)$

$\Delta \mathrm{T}=$ Observation interval $(\mathrm{jam})$

\section{Stress-strain studies}

Stress studies were performed by applying a stress instrument to the EF with specific thickness and size. First, the instrument was set up with a load of $100 \mathrm{kgf}$ with stress rate of $50 \mathrm{~mm} / \mathrm{min}$ and then the film was clamped on that instrument. The film was pulled until broken and the maximum stress $\left(\mathrm{F}_{\max }\right)$ and strain were observed. The strain data were converted to tensile strength $\left(\delta_{t}\right)$ and elongation $(\varepsilon)$.

\section{RESULTS AND DISCUSSION}

The physicochemical properties of EF from GAP are shown in Table 2. The thickness of the EF was measured using a micrometer, and the

Table 2: Thickness, water vapor permeability, tensile strength, and thermal decomposition of GAP EF

\begin{tabular}{|c|c|c|c|c|c|c|}
\hline \multirow[t]{2}{*}{ Parameter } & \multicolumn{6}{|l|}{ Sample } \\
\hline & $\mathbf{E F}_{1}$ & $\mathbf{E F}_{2}$ & $\mathbf{E F}_{3}$ & $\mathrm{EF}_{4}$ & $\mathbf{E F}_{5}$ & $\mathbf{E F}_{6}$ \\
\hline Thickness of film $\left(\times 10^{-2} \mathrm{~mm}\right)$ & 3.2 & 3.8 & 6.0 & 6.4 & 7.8 & 8.2 \\
\hline WVP $\left(\times 10^{-9} \mathrm{~kg} / \mathrm{s} / \mathrm{m} / \mathrm{Pa}\right)$ & 3.483 & 4.665 & 6.606 & 6.398 & 0.721 & 0.796 \\
\hline Tensile strength (MPA) & 20.400 & 12.280 & 4.502 & 2.600 & 1.920 & 3.860 \\
\hline Elongation $(\%)$ & 1200.28 & 70.050 & 71.092 & 55.350 & 27.610 & 48.560 \\
\hline Endothermic $\left({ }^{\circ} \mathrm{C}\right)$ & 80 & 80 & 80 & 80 & 80 & 80 \\
\hline Exothermic $\left({ }^{\circ} \mathrm{C}\right)$ & 315 & 305 & 325 & 315 & 330 & 325 \\
\hline
\end{tabular}

EF: Edible film, GAP: Galactomannan from Arenga pinnata 
water vapor permeability was calculated based on regression values of the different weights of the desiccant with time, tensile strength, and thermal decomposition of GAP EF.

Water vapor permeability is one of the most important properties which influence the utilization of EF as water could deteriorate the sample [8]. As shown in Table 2, the values of WVP changed with the increasing concentration of GAP in the films at the same concentration of glycerol and MGO. However, further increase of GAP concentration decreased the WVP values quickly, which was presumably due to the increase of a gel network which made the polysaccharide become dense rendering the formation of a more cohesive film structure [9].

The EF production from GAP incorporated with ZOE resulted in six different films: $\mathrm{EF}_{1}-\mathrm{EF}_{6}$. The thicknesses of the EF were determined at five different points using a micrometer, and the means were calculated in the range of $0.032-0.082 \mathrm{~mm}$, which shows that increasing the amount of GAP and ZOE increased the thickness of the film. The thickness of the GAP EF occurred in the range of 0.032$0.082 \mathrm{~mm}$. This result is similar to the results of other researchers who reported that the hydrophobic addition could reduce WVTR/ WVP value [16].

Thermal properties of all EF showed an endothermal temperature of $80^{\circ} \mathrm{C}$, which means that the amount of GAP and ZOE does not affect water release from the film. We assumed that the small amount of compound used affects the interaction between water and galactomannan, which remained stable even with the appearance of hydroxyl, aldehyde, and alkene functional group from $\mathrm{ZOE}$. The samples of $\mathrm{EF}_{1}-\mathrm{EF}_{6}$ were degraded at a temperature above $300^{\circ} \mathrm{C}$, which could be used for food that is produced at high temperature. In addition, exothermal temperature decreased with the increase of ZOE, but the effect was contrary to the increase of galactomannan.

Tensile strength and elongation were also affected by compounds in the films, as both values decreased with the addition of ZOE. This was because ZOE acted as a plasticizer which makes the structure became rigid, increasing the mobility, and decreasing crack resistance [7].

Each EF was identified using FT-IR to find out the changes of functional group in galactomannan when interacting with ZOE. Fig. 1 shows the FT-IR spectrum of EF number 3 and GAP. FT-IR was used in this research to study the interaction between two or more compounds. Absorbance data of specific wavelength could give quantitative data [17].

The spectra of galactomannan showed characteristic peaks which were similar to previous reports $[6,18]$. The stretching vibration peak at $3310 \mathrm{~cm}^{-1}$ is related to $\mathrm{OH}$ groups from polysaccharide, while the peak at $2919 \mathrm{~cm}^{-1}$ belongs to the characteristic absorption of stretching $-\mathrm{C}-\mathrm{H}$ from $-\mathrm{CH}_{2}$. The peak at $1640 \mathrm{~cm}^{-1}$ represents the polysaccharide bond. The broadband in the area of $900-1200 \mathrm{~cm}^{-1}$ was due to stretching vibration of $-\mathrm{C}-\mathrm{C}-\mathrm{O}, \mathrm{C}-\mathrm{OH}$, and $\mathrm{C}-\mathrm{O}-\mathrm{C}$ from the main polymer chain [19]. The peak ascribed to bending vibration $\mathrm{C}-\mathrm{O}$ from pyranose ring was recorded at $1146 \mathrm{~cm}^{-1}$ while the peak at $871 \mathrm{~cm}^{-1}$ was characteristic to $\beta$-D-mannopyranose, and at $813 \mathrm{~cm}^{-1}$ represented the $\alpha$-D-galactopyranose bond [19]. The FT-IR spectra of GAP and $\mathrm{EF}_{3}$ were almost similar, which means there was no change in the functional group after mixing. However, there were appreciable changes in the $\mathrm{EF}_{3}$ spectra in the appearance of a peak at $1735 \mathrm{~cm}^{-1}$ which is related to the stretching vibration of $\mathrm{C}=0$ group from $\mathrm{ZOE}$. Furthermore, some differences were also observed after film formation in which the medium absorbance peak of $\mathrm{OH}$ group at $3000-3500 \mathrm{~cm}^{-1}$ and the sharp peak of $\mathrm{C}-\mathrm{OH}$ at $900-1200 \mathrm{~cm}^{-1}$ became weak absorbance, which was probably due to interaction compound between GAP and ZOE [20].

SEM was used to investigate the morphological image of the EF as shown in Fig. 2. The SEM images of the EF, formed from a mixture of GAP, MGO, and ZOE, revealed some changes in the film surface. The smooth surface, as shown in Fig. 2c, was due to the addition of MGO to the EF rendering a stable film with the ZOE distributed evenly on the surface of the film.

\section{Antibacterial activity}

Gupta and Ravishankar reported that ginger paste has antimicrobial activity against Escherichia coli [21]. Based on that, the antibacterial activity of the EF and ZOE was studied using fresh 0 . niloticus fish with the standard plate count method. As shown in Fig. 3, the O. niloticus fish was used to determine the ability of the EF and ZOE to inhibit bacterial

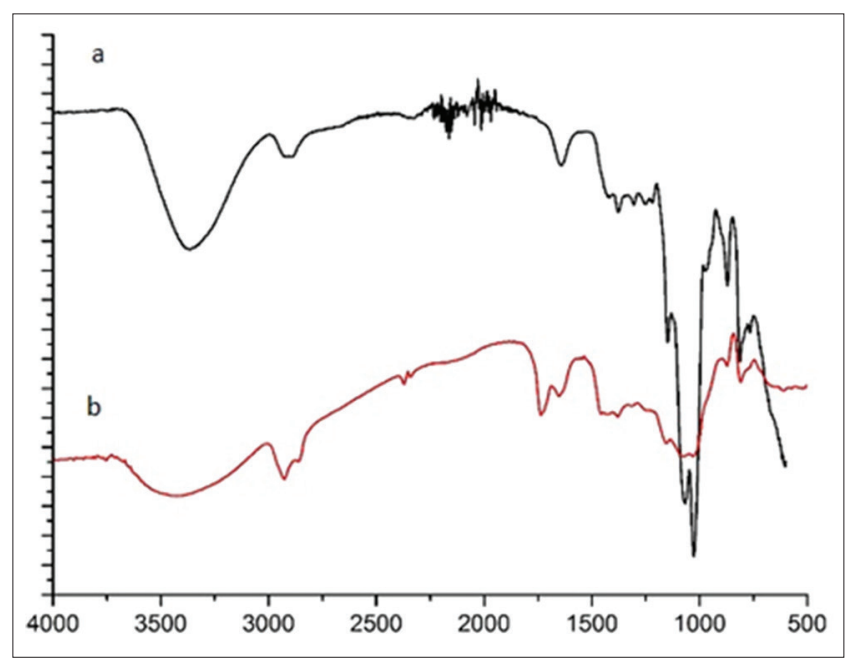

Fig. 1: The Fourier transform infrared spectrum of galactomannan from Arenga pinnata (a) and edible film ${ }_{3}$ (b)

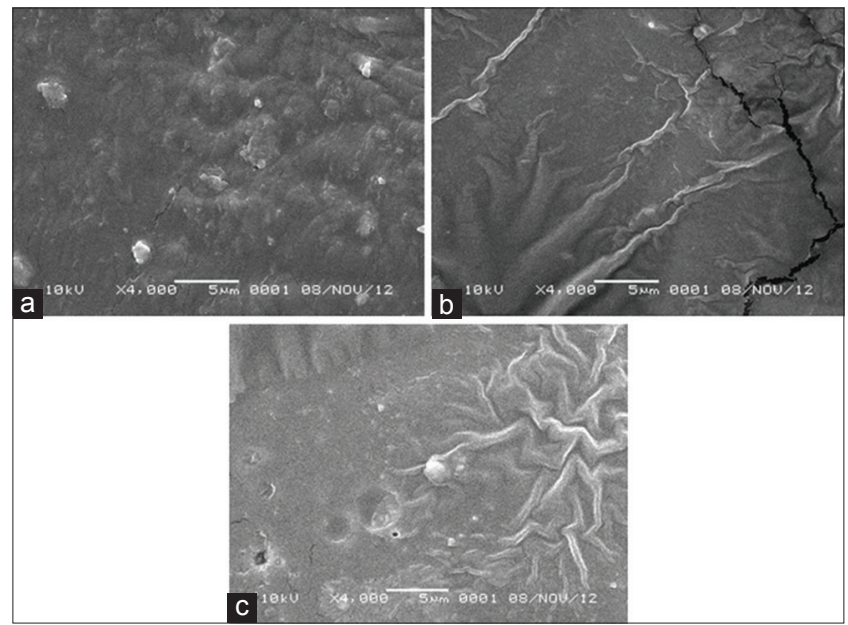

Fig. 2: The image of surface morphology of galactomannan from Arenga pinnata (GAP) edible film. (a) SEM EF of GAP + glycerol $(0.9 \mathrm{~g}+0.6 \mathrm{~g})$, (b) SEM EF of GAP + glycerol + Zingiber officinale essential (ZOE) $(0.9 \mathrm{~g}+0.6 \mathrm{~g}+0.5 \mathrm{~g})$, (c) SEM EF galactomannan + glycerol + MGO + ZOE $(0.9 \mathrm{~g}+0.6 \mathrm{~g}+0.2 \mathrm{~g}+0.5 \mathrm{~g})$

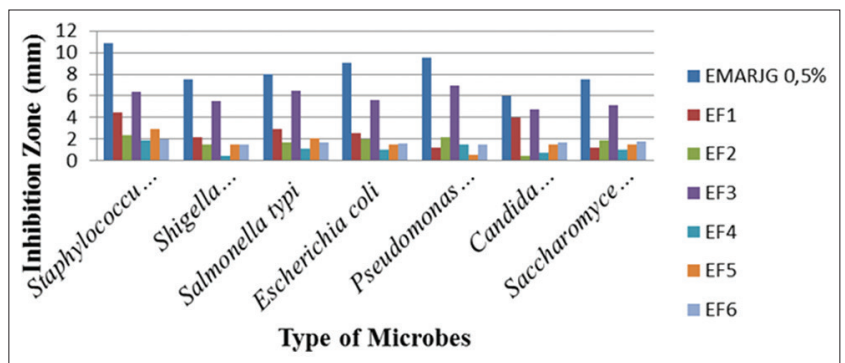

Fig. 3: Antibacterial activities of the edible film $\left(\mathrm{EF}_{1}-\mathrm{EF}_{6}\right)$ 
growth in vivo. The results in Fig. 4 showed that the amount of bacteria until day 5 remains below the standard value compared to the control sample, which means that both EF and ZOE have antimicrobial activities. The lower amount of bacteria compared to the control demonstrated that the active compound contained in the EF and ZOE was released starting from day 1 to day 5 . The bacteria amount increased after day 5 , which was due to the decrease of the concentration of the active compound in both the EF and ZOE. Therefore, it can be concluded that the EF and ZOE have antimicrobial activity and could inhibit bacterial until day 5 .

\section{Respiration rate}

Respiration rate is an important factor in the future application of EF [7]. The respiration rate is usually determined by measuring the consumption rate of $\mathrm{O}_{2}$ or the production rate of $\mathrm{CO}_{2}$. The respiration

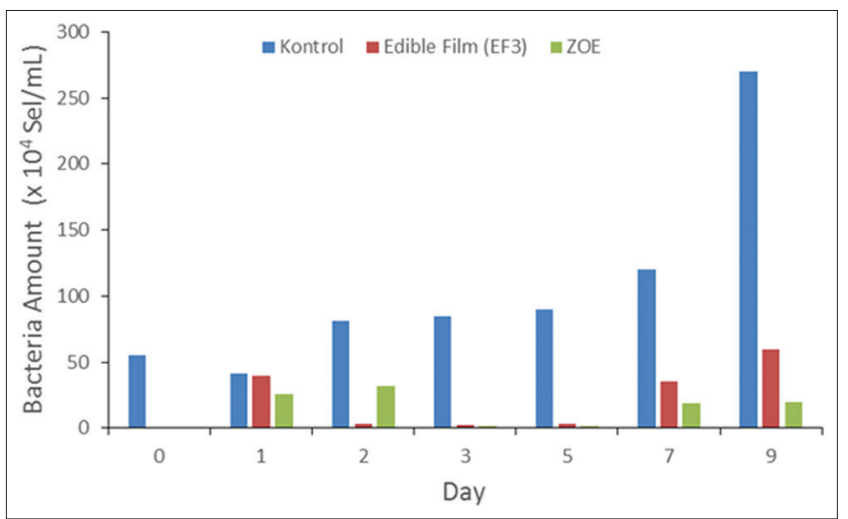

Fig. 4: Estimation of the density of bacteria using standard plate count method

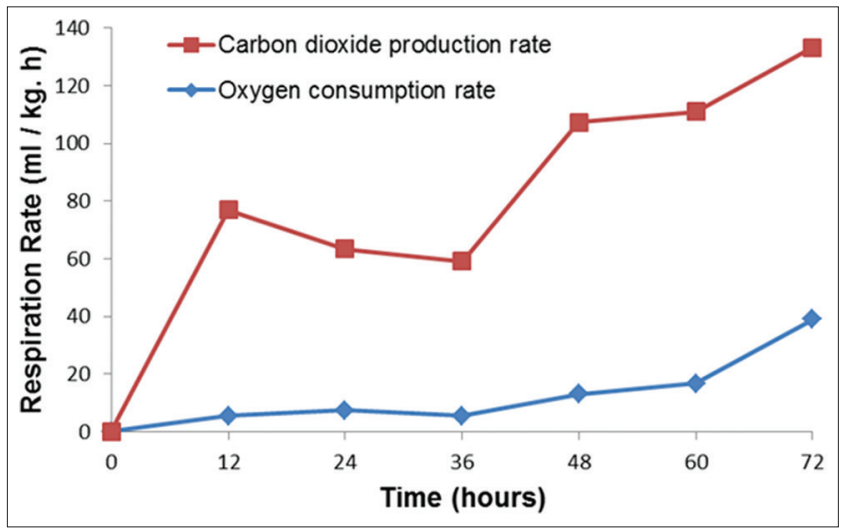

Fig. 5: Respiration rates of unwrapped Oreochromis niloticus fish

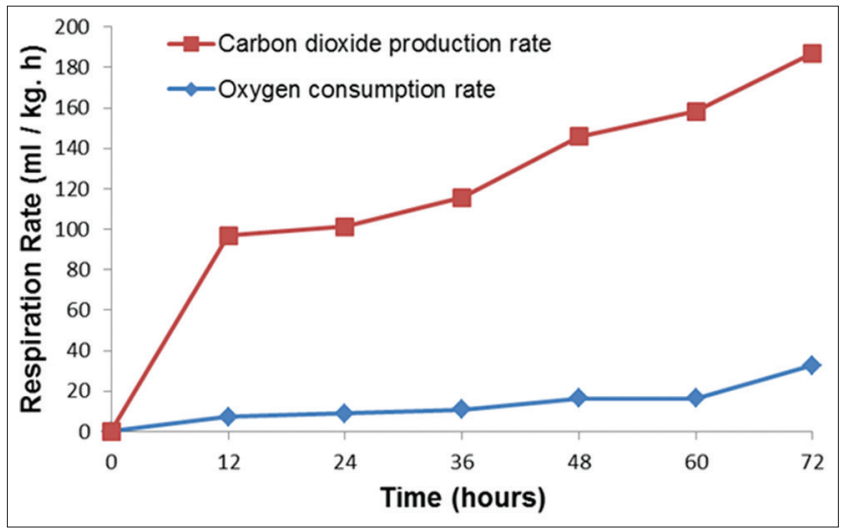

Fig. 6: Respiration rates of wrapped Oreochromis niloticus fish rates of oxygen and carbon dioxide of EF wrapped around fresh O. niloticus fish with the determined interval of time at $12 \mathrm{~h}$, at $10^{\circ} \mathrm{C}$ storage temperature, are presented in Figs. 5 and 6. Significantly different results were found in the oxygen consumption of wrapped and unwrapped fresh 0 . niloticus fish. The wrapped fish sample had a low oxygen consumption rate compared to the unwrapped sample, while the carbon dioxide production rate remained similar for both samples. The lowest oxygen consumption rate was presumably due to the raw material used for the production of the EF, hydrocolloid, which can inhibit oxygen migration. The respiratory quotient (RQ) of the EF was 7.71, which came from the carbon dioxide production rate divided by the oxygen consumption rate, at $101.812 \mathrm{~mL} / \mathrm{kg}$ hour and $13.204 \mathrm{~mL} / \mathrm{kg}$ hour, respectively. The RQ value of more than 1 means that substrate is containing oxygen, such as organic acid, which was used in respiration [22].

It can be concluded that the addition of MGO in the preparation of GAP EF makes the surface of the film smooth. ZOE can decrease WVP and the tensile strength of GAP EF. Especially in $\mathrm{EF}_{4}, \mathrm{ZOE}$ was able to affect the formation of FT-IR wavelength at $3100-3500 \mathrm{~cm}^{-1}, 1635 \mathrm{~cm}^{-1}$, and $800-1200 \mathrm{~cm}^{-1}$. The results of the antibacterial activities against seven bacteria showed that the films $\left(\mathrm{EF}_{2}, \mathrm{EF}_{3}\right.$ and $\left.\mathrm{EF}_{4}\right)$ had growth inhibition of $S$. aureus.

\section{ACKNOWLEDGMENTS}

The authors acknowledge the financial support from Directorate General of Higher Education - Ministry of Research, Technology and Higher Education, Indonesia, and the Rector of University of Sumatera Utara by DIPA USU 2013 on 4267/UN5.1.R/KEU/2013, date of June 3, 2013. The authors would like to acknowledge Maria Flutsch for editing the manuscript.

\section{AUTHORS' CONTRIBUTIONS}

Juliati Br. Tarigan (JBT), Irwana Nainggolan (IN), and Jamaran Kaban (JK) conducted the experiments. JBT wrote and edited the manuscript.

\section{CONFLICTS OF INTEREST}

The authors declare that they have no conflicts of interest.

\section{REFERENCES}

1. Lin D, Zhao Y. Innovations in the development and application of edible coatings for fresh and minimally processed fruits and vegetables. Compr Rev Food Sci Food Saf 2007;6:60-75.

2. Vargas M, Pastor C, Chiralt A, McClements DJ, González-Martínez C. Recent advances in edible coatings for fresh and minimally processed fruits. Crit Rev Food Sci Nutr 2008;48:496-511.

3. Ponce AG., Roura SI., Del Valle CE, Moreira MR. Antimicrobial and antioxidant activities of edible coatings enriched with natural plant extracts: In vitro and in vivo studies. Postharvest Biol Technol 2008;49:294-300.

4. Malhotra B, Keshwani A, Kharkwal H. Natural polymer based cling films for food packaging. International Journal of Pharmacy and Pharmaceutical Sciences 2015;7,4,10-8.

5. Abouhussein DMN, El-Bary AA, Shalaby SH, Nabarawi MAE. Chitosan mucoadhesive buccal films: Effect of different casting solvents on their physicochemical properties. International Journal of Pharmacy and Pharmaceutical Sciences 2016;8:206-13.

6. Tarigan JB. Karakterisasi Edible Film Yang Bersifat Antioksidan Dan Antimikroba Dari Galaktomanan Biji Aren (Arenga pinnata) Yang Diinkorporasi Dengan Minyak Atsiri Daun Kemangi (Ocimum basilicum 1.) [Disertasi]. Medan: Universitas Sumatera Utara; 2014.

7. Cerqueira MA., Souza BW, Martins JT, Teixeira JA, Vicente AA. Seed extracts of Gleditsia triacanthos: Functional properties evaluation and incorporation into galactomannan films. Food Res Int 2010;43:2031-8.

8. Cerqueira MA, Lima ÁM, Teixeira JA, Moreira RA, Vicente AA. Suitability of novel galactomannans as edible coatings for tropical fruits. J Food Eng 2009;94:3-4, 372-8.

9. Cerqueira MA, Lima AL, Souza BW, Teixeira JA, Moreira RA, Vicente AA. Functional polysaccharides as edible coatings for cheese. J Agric Food Chem 2009;57:1456-62. 
10. Tarigan JB, Barus T, Marpongahtun KJ. Characteristic and Study of Antioxidant Activity Galactomanan from "Kolang-Kaling" (Arenga pinnata). Penang: Asian International Conference on Materials, Mineral and Polymer; 2012.

11. Sultan M., Bhatti HN, Iqbal Z. Chemical analysis of essential oil. Of ginger (Zingiber officinale). Pak J Biol Sci 2005;8:1576-8.

12. Toure A, Xiaoming Z. Gas chromatographic analysis of volatile components of Guinean and Chinese ginger oils (Zingiber officinale) extracted by steam distillation. J Agron 2007;6:350

13. El-Baroty GS., El-Baky HA., Farag R, Saleh MA. Characterization of antioxidant and antimicrobial compounds of cinnamon and ginger essential oils. Afr J Biochem Res 2010;4:167-74.

14. Bozdemir ÖA, Tutaş M. Plasticiser effect on water vapour permeability properties of locust bean gum--based edible films. Turk J Chem $2003 ; 27: 773-82$

15. Fardiaz S. Mikrobiologi Pangan 1. Jakarta: Gramedia; 1992.

16. Cerqueira MA, Bourbon AI, Pinheiro AC, Martins JT, Souza BW, Teixeira JA, et al. Galactomannans use in the development of edible films/coatings for food applications. Trends Food Sci Technol 2011;22:662-71.

17. Pelissari FM, Grossmann MV, Yamashita F, Pineda EA. Antimicrobial, mechanical, and barrier properties of cassava starch-chitosan films incorporated with oregano essential oil. J Agr Food Chem 2009;57:7499-504

18. Boual Z, Pierre G, Delattre C, Benaoun F, Petit E, Gardarin C, et al. Mediterranean semi-arid plant Astragalus armatus as a source of bioactive galactomannan. Bioact Carbohydr Diet Fibre 2015;5:8-10.

19. Buriti FC, Dos Santos KM, Sombra VG, Maciel JS, Teixeira Sá DM, Salles HO, et al. Characterisation of partially hydrolysed galactomannan from Caesalpinia pulcherrima seeds as a potential dietary fibre. Food Hydrocol 2014;35:512-21.

20. Prosapio V, Reverchon E, De Marco I. Incorporation of liposoluble vitamins within pvp microparticles using supercritical antisolvent precipitation. J CO2 Util 2017;19:230-7.

21. Gupta S, Ravishankar S. A comparison of the antimicrobial activity of garlic, ginger, carrot, and turmeric pastes against Escherichia coli O157: H7 in laboratory buffer and ground beef. Foodborne Pathog Dis 2005;2:330-40.

22. Pantastico EB. Post-Harvest Physiology, Handling and Utilization of Tropical and Subtropical Fruits and Vegetables. Westport: Avi Publishing Company, Inc; 1975. p. 560. 